\title{
Hezkuntza-komunitatearen zeregina kultura ondarearen transmisioan
}

Iñigo Ramirez de Okariz Telleria

Berrikuntza eta Eskuhartzea Gizarte Kulturanitzetan eta Eleanitzetan Humanitateak eta Hezkuntza Zientzien Fakultatea

Mondragon Unibertsitatea

DOI: $10.1387 /$ tantak.14456

GAKO-HITZAK: Kultura-ondarea, transmisioa, dialogoa, testuinguru soziokulturala, hezkuntza-komunitatea, Lehen eta Bigarren Hezkuntza.

\section{SARRERA}

XIX. mendean ondarearen ikuspegia mugatua, singularra, antzinakoa, monumentala eta artistikoa bazen ere, ikusmira hori gainditu egin da Xx. mendean zehar. Izan ere, Xx. mendearen laurogeiko hamarkadatik aurrera ondareari «kultura» adjektiboa atxiki zaionetik, kontzeptu honek hartu du protagonismoa. Horrela, artikulu honetan, bat egin nahi dugu guk ere Cuencak (2002) nahiz Prats-ek (2009) berari eman nahi dioten iritzi eta ikusmira globala nahiz holistikoarekin. Eta hala, kultura ondarea, inguru natural eta sozial batean gizakiok eragindako prozesu bezala ulertu, non ikuspegi osoa aplikatzea beharrezkoa den.

Ikuspegi global eta holistiko hau aitortuz, Estepa eta Cuencaren (2006:51-71) iritzi honekin ere bat egin nahi dugu:

Nos enfrentamos al concepto de patrimonio desde una perspectiva sistémica, integradora y compleja, donde los referentes patrimoniales se articulan como un único hecho sociocultural constituido de manera holística, por diversas manifestaciones de carácter histórico, artístico, etnológico, científico-tecnológico y natural, que en conjunción permiten el conocimiento integral de las diferentes sociedades tanto del pasado como del presente, dando lugar a estructuras de identidad social que se convierten en símbolos culturales.

Hezkuntzan begirada jarriz, Xx. mendean zehar hezkuntza joerak hiru multzotan bana daitezkeela esaten digu kultura-ondarean aditua den Roser 
Calaf-ek (2008). Hala, lehen multzoan transmititu, ezarri, erreproduzitu izan baziren ere hezkuntza tradizionalak bultzatu nahi izan zituenak, gizartearen beraren statu quo delakoari eusteko, bigarrenean, bultzatu, erraztu, proposatu, pentsatu eta eraldatu izan ziren eskola aktibotzat hartu zen mugimenduarekin loturiko nahiak. Hirugarrenean, berriz, eta bigarrenetik abiatuta, hezkuntzaren kritikan oinarritutako mugimendu eta pentsalariekin bat egiteko aukera dugu besteak beste, hausnartu, kontzientziatu, liberatu gehituz.

Eta horretarako, alde batetik, Gizarte Zientzien irakaskuntza-ikasketa prozesuan kultura ondarea erreminta indartsua eta eraginkorra izan daitekeela esatea ez da baieztapen berria, eta inork ez du zalantzan jartzen ondare-elementuen erabilerak erraztu egiten duela inguratzen gaituen inguruneaz ditugun galderak modu zuzenean erantzutea, hausnartzea, eta ondoren ondorioetara ailegatuz gure ingurune soziala nola eraikitzen den hautematea.

Beste alde batetik, eskolari «komunitate» hitza edo kontzeptua atxikitzea ez da berria, izan ere sarri erabili izan ditugu «eskola-komunitatea» edo «hezkuntza-komunitatea» bezalako kontzeptuak edo metaforak bizipenak partekatzen dituen pertsona multzo baten (irakasle, ikasle, guraso, beste langileak) harremanak adierazteko, betiere helburu jakin batzuk lortze aldera,. Hala ere, bata zein bestea lotuago daude eskola- edo hezkuntza-elementuekin komunitatearekin baino, eta hori kaltegarria izan liteke; alegia, eskola komunitatea ezagutza eta gaitasunen erakunde sortzaile gisa soilik ulertzea, belaunaldi, kultura-eredu, balio eta elkar bizitzeko eta harremanak egiteko era desberdinak duen toki bezala ulertu beharrean. Beraz, nahia da elkarren arteko menpekotasunaren, elkarrekiko eraginaren ideia jasotzea, izan ere eskolan dauden eragileak daude, baita tokiko komunitatean ere bada eragilerik, eta ez da bata bestea barik ulertzerik.

Ez luke egon behar beraz etenik. Eskolako nahiz komunitate bateko gaiak ukitzerakoan eskola-komunitate batetik ezin baitira soilik, esklusiboki eskolatik bertatik landu; eta alderantziz. Hots, eskolatik egin daiteke kultura, hirigintza ... eta tokiko komunitatetik hezkuntzaz, irakaskuntzaz eztabaida genezake, baita hezkuntza-eduki eta balioez ere. Kolektibitate batek guzti horiei aurre egiteko gai dela onartuko balu, orduan eskolako komunitatea kanpoko gaia ere bihurtuko litzateke, denak elkarren beharrean aurkitu arte. Ideia hauek badakarte beste aldaketa bat: elkarren arteko botere-ereduarena, zeinak eskolako ohiko harreman bertikaletatik horizontalagoetara pasaraztea dakarren, eta eskola eta tokiko komunitatearen artekoak komunitateen artekora (Subirats, 2002:40-41).

Pero, ¿cómo aprender a vivir juntos en la «aldea planetaria» si no podemos vivir en las comunidades a las que pertenecemos por naturaleza: la nación, la región, la ciudad, el pueblo, la vecindad? El interrogante central de la democracia es si queremos y si podemos participar en 
la vida en comunidad. Quererlo, no lo olvidemos, depende del sentido de responsabilidad de cada uno (Delors, 1996:10).

Nola erantzun desafio horri? Bada, norberaren sustraiak galtzeke eta parte hartuz bakoitzak bere komunitatean (Delors, 1996).

Gertuko ondarearen sustraiari erreparatuz, Alberto Santanak (1995:252) beharrezkotzat jotzen du: «la difusión directa y concienciación de quienes son sus primeros usuarios y responsables: los escolares, las familias, la comunidad de vecinos y el ayuntamiento. Pero por lo que respecta al ámbito específico de la escuela, el estudio y el análisis del Patrimonio debe ofrecerse en primer lugar como una herramienta para comprender e interpretar el entorno más inmediato al alumno, aportándole criterios para valorar, relativizar, defender o criticar tanto los logros como las propias contradiciones de su herencia cultural».

Are gehiago indartzen du Henrik Zipsane-k Alberto Santanak adierazitako ideia hori:

Finally, we should consider how cultural heritage learning is related to the learning process, wich is often characterised as formal, nonformal or informal learning. It is often tempting to depict cultural heritage learning only as part of the informal learning processes. However, if we examine up to date and current definitions of these three fundamental learning processes, we have reason to once again reflect on where cultural heritage learning belongs. (Henrik Zipsane, $\mathrm{d} / \mathrm{g}: 5$ ).

Esandakotik abiatuta, eta artikulu honen helburu nagusia kultura ondarearen transmisioaren baitan, bera eta hezkuntza-komunitatearen eragileen (formala eta ez formalen) arteko didaktikarako argudio teorikoaren bilaketan oinarritzen denez, uste dugu horretarako beharrezkoa dela hezkuntza ez formalari, ikaskuntza komunitarioari eta paradigma soziokulturalei buruz hausnartzea, horretarako aintzat hartuaz John Dewey $(1982,1985,2004)$, Paulo Freire $(1975,1985)$, David Ausubel (1962, 1963), Lev Vygotski (1979), Ramón Flecha $(1997,2001)$ eta Howard Gardner-en $(1983,2005)$ irizpideak eta esanak alde batetik, eta gure testuinguru soziokulturalera egokitzeko bestetik, Paulo Iztueta (1996) eta Gurutze Ezkurdiaren (2004) adierazpenak barne.

\section{DEWEY ETA ESPERIMENTAZIOAREN PRINTZIPIOA}

Gure garaian gertatzen diren aldaketek hezkuntza bera ulertzeko eta praktikatzeko moduak aldatu ditu modalitate guztietan, eta baita bizitzarekin eta kulturarekin dituen harremanak ere. Hala, hezkuntza berrien beharrak eramaten gaitu, sarri, perspektiba zabala izatera eta umearen ahalmen 
intelektualak eta moralak hobeto garatzeko edo biribiltzeko garai bateko adituak berreskuratzera. Ariketa horrek ez du zertan anakronismoa izan; oso bestela, egungo hezkuntzaren errealitatea ulertzeko eta hezkuntzari beste perspektiba bat emateko bitartekari onak direlakoan gaude: «No sería una señal de buena salud si un interés social tan importante como la educación no fuera también un campo de lucha, práctica y teóricamente» (Dewey, 2004:7).

Esaldi horretan laburbiltzen du Dewey-k bere pentsamendu eta zereginaren nondik norakoa eta berak abian jarri zuena, izan ere oso kritikoa izan zen pentsamendu tradizionalarekin, hots, ez baitzitzaion iruditzen hezkuntza bat zetorrenik programen interesekin eta garatzen zituzten aktibitateekin; eta horri aurre egin nahian, bada, esperientzia nahiz esperimentazioan oinarritutako ikasketa-gaiak bultzatu nahi izan zituen, eta horretan aritu ahal izateko, irakasleen lana eta beren profilaren aldaketa beharrezkoa bezain oinarrizkoa zela ikusi zuen. Zer gaitasun aintzat hartu behar zuen bada profil berri horrek? Hiru hezkuntza mailako gaitasun eduki behar ziren: irakatsi nahi duten ikasgaien ezagutza ona izatea (1); umearen psikologian ere ezagutza izatea (2) eta umearentzat estimulagarriak izan zitezkeen estrategia metodologiko aproposen gaitasunetan ere aditua izatea (3).

\subsection{Dewey eta elkartruke komunitarioa}

Deweyrentzat prozesuen batuketa oso bat da hezkuntza, eta prozesu horien bitartez gizarte bat edo gizatalde handi nahiz txikiak bereganatutako botereak, gaitasunak eta idealak transmititzen ditu, haren iraupena eta garapena mantentzeko. Aldi berean, bi eratako hezkuntza bereizten ditu: hezkuntza asistematikoa edo eskolatik kanpokoa (askoz garrantzitsuagoa, sakonagoa eta erreala, umeak etxean, kalean edo sozializatzeko beste eremuetan jasotakoa), eta hezkuntza formala edo eskolarra, abstraktuagoa eta azalekoa, eragin gutxiago duena, baina aldi berean zabalagoa, osoagoa eta segurua. Arazoa da nola ondo artikulatu euren arteko (ikasketa formala eta ingurunearen eguneroko bizipenak) elementu positiboak. Beraz, berarentzat hezkuntza berreraikitzen jarraitzea da (Dewey, 1985).

Hezkuntza ez formalari ematen dion garrantzia azpimarratzekoa da, beraz, «garrantzitsua, sakona, erreala» ideiak erabiltzen ditu hori adierazteko, eta, aldi berean, hiru ideia azpimarratzen ditu hezkuntza ez formalaren baitan txertatzeko; alegia, esperientziaren boterearena, interesaren garrantziarena eta jolasarena (Dewey, 1985:160).

Aldi berean, prozesu bat bezala ulertzen du esperientzia-metaketa, batak besteari ematen dio zentzua, bai eta beste bat eraikitzeko aukera ere; beraz, elkarreraginaren printzipioa teorizatzen du. Esperientzia hori aberasteko, gainera, bere herriko baina eskolako testuingurutik kanpoko beste 
errealitate geografiko, historiko, ekonomiko, kulturalak... (ikasketa informala deitzen dio berak) bultzatzea garrantzitsua dela ikusten du; alegia, esaten du ingurunea bitartekari ona dela aktibitate-printzipioa aktibatzeko, eta, aldi berean, baita elkartruke komunitarioa ere (Dewey, 1985:41). Beraz, hemen ikusten ditugu azpimarratuta guk artikulu honetan elkarlotu nahi ditugun hiru ideiak: hezkuntza formala, ez formala eta komunitatea (elkartruke komunitarioa).

Esperientziaren boterea ikasketa prozesuan oinarrituta, museoen, interpretazio-zentroen, toki historikoen eta abarren behaketa zuzenean aplikatu daiteke, eta gaur egun hain boladan dagoen hezkuntzaren berreraikuntzaren ideian (edo gaur egungo psikologia konstruktibista delakoan) oinarritu zuen hori Deweyk (1982:81):

«La tarea del educador consiste primero en seleccionar el material adecuado para determinar la naturaleza de las representaciones subsiguientes sobre la base del caudal de ideas ya adquiridas por transacciones anteriores (...). Puede establecerse ciertas etapas formales para todos los métodos de enseñanza (...). A la presentación sigue el proceso de interacción de lo viejo con lo nuevo; después viene la aplicación del contenido nuevamente formado a la realización de alguna tarea».

Hezkuntza berreraikuntza gisa hartuta, Deweyk (1982) adierazten digu esperientzia egin eta gero ikasten dugula; izan ere, orduan konturatzen gara lehen hauteman gabeko emaitzekin, eta, beraz, behatu eta esperimentatu dugunaren arteko loturarekin. Ikusten dugun bezala, baliagarria da, halaber, prozesuaz konturatzen garelako; hau da, esperientzia batek zentzua ekintza askoren ondorioz hartzen duenaz.

Ikasteko aktibitateak egiten dituztenen artean interesa piztekoak ere funtsezkoak dira irakaskuntza-ikasketa prozesuan. Deweyren (1982) planteamenduaren arabera, objektu eta subjektuen arteko elkarrekintza ezinbestekoa denez, irakaslearen zeregin garrantzitsuena ikaslearentzat helburu izan eta, aldi berean, erakargarriak diren material egokiak aurkitzea da. Jolasak jarduera interesgarriak dira interes hori pizteko.

Jolasa eta lana ondo berezi eta, halaber, ondo uztartu beharreko bi aktibitate garrantzitsu dira eskolaren testuinguruan. Jolasa, baina, xede esanguratsu bihurtzen da.

Calafek adierazten digu (2008) Deweyk 1929an idatzitako La escuela y la sociedad izeneko liburuan hezkuntza ez formalarekin (museoarekin) lotutako aipamen zuzenak aurki daitezkeela, bertan azpimarratuz nolakoa izan beharko litzatekeen gizartea eraldatuko lukeen eskolaren arkitektura, non sarritan gertatuko litzatekeen teoria eta praktikaren arteko lotura. Alegia, ezinbesteko izango litzateke esperimentazioan oinarritutako irakaskuntza, baina baita iragana eta oraina lotzeko espazio batean, eta euren arteko dialektika ere beharrezkoa ikusten du; horretarako, laborategiak diseina- 
tzeaz gain, museoa ere proposatzen du, laborategien eta jarduera artistikoak jorratu diren esperimentazioen toki osagarritzat hartuta.

Laburbilduz, bada, interesean, jolasean eta esperimentazioan oinarritzen da berak eskaintzen digun pentsamendua, baina hezkuntza ez formalaren baitan dauden museoak, interpretazio zentroak edo bestelakoak egon daitezkeen dialektikak ahaztu gabe, batez ere errealitatea eraldatze prozesua dela hautemateko, alegia, kontuan hartuta lehenaren eta orainaren arteko alderaketa egitea beharrezkoa dela egoera errealak ulertzeko. Beraz, printzipio garrantzitsuak dira kultura-ondarearen didaktika diseinatzeko.

\section{FREIRE ETA IKASKETA DIALOGIKOA}

Gaur egungo gizartearen pentsamendu bakarraren aurrean - neoliberalismoak eta postmodernitateak ezarria eta eurak ezarritako gizakion morrontzan oinarritua-, badago gizarte-zientzien ildotik joera kritiko bat. Hezkuntza kritiko horren abiapuntu, baina, La pedagogía del oprimido (1985) kulturaz eta hezkuntzaz hainbeste jardun zuen Freire pedagogoa izan zen.

Izan ere, Freireren ustez (1985) hezkuntzaren ikusmolde tradizionala, edo bere hitzetan adierazten duen bezala hezkuntza bankarioa dena eta irakaskuntza-edukiak transferitze hutsean oinarritzen dena, hau da, elkarrizketari, kreatibitateari eta kontzientziari, ateak ixten dizkiona, eraldatu beharra dago, eta hezkuntza askatzaile edo kritiko bat errebindikatu behar da; edo haren beste ideia bat baliatuz, modu kritikoan hurbildu behar da errealitatera: «conciencia transitiva ingenuatik» «conciencia transitiva critícara» igaro behar da (Freire, 1975:54-56). Alegia, arazoen interpretazio sinpleetatik, argudio hauskorretatik, dialogo gabeziatik, elkarrizketan, aktibitatean oinarritutako hezkuntzara.

Hezkuntza kritikoan teoria eta praktika maila berean egotea aldarrikatzen du Freirek. Hezkuntza mota hori ez da, gainera, irakaskuntzaren transmititze soilean geratuko, eduki hutsetik haratago joango delako. Berak esandakoari jarraituz, irakastea ez da ezagutza jakitea, baizik eta hura sortzeko edo erabiltzeko ahultasunak sortzen jakitea (Tejados, 2005). Edukiak, beraz, eraiki egin behar dira, baina horretarako Hezkuntza Komunitate guztiak (irakasleek, ikasleek, gurasoek, erakundeek, elkarteek) parte hartu behar dute, hau da, taldean eraiki behar dira edukiak. Ikaskuntza-komunitate horretan irakaslea bitartekaria da curriculumeko ekintzen garapenean. Irakasle-ikasle harremanak horizontalak izatea eta agerian lagatzea dakar horrek. Horregatik da garrantzitsua eraikitze prozesu hori, irakasle eta ikasleek elkarrekin ikasi, irakatsi, kezkatu, ekoiztu eta elkarrekin aurre egin behar baitiete eragozpenei (Tejados, 2001). Ikuspuntu hori interesgarria da guretzat, museoekin, interpretazio-zentroekin edo besteekin elkarreraginez, kultura-ondarearekin loturiko komunitate hezitzaile bat diseinatu ahal izateko (Calaf, 2008). 
Freiren eraikitze prozesu horretan aurrera eramango duen metodologia dialogikoa izango da. Jakina, «dialogo» hori ez da elkarrizketa hutsean gauzatuko, baizik eta taldean egindako gogoeta-ekintza bat izango da, eta inplizituki aldaketa dakar berarekin, eraldaketa, horixe baita, eraldaketa teoria guztiaren azpian dagoen helburua (Tejados, 2005).

Gure eguneroko praktikan baditugu Freireren isla diren esperientzia batzuk; horietako bat ikaskuntza-komunitatearen proiektua da. Eta Ramón Flecharen esanetatik (2001a), eta berarentzat ikaskuntza-komunitateaz nahiz berak sorrarazitako elkarrekintzaz aritzen zaigunean esaten digu kontzeptu horiek guztiak gaurko Gizarte Zientzietatik jasotzen ditugunak direla, eta ez hezkuntzan aplikatu ohi diren teoria atzerakoietatik hartuak. Gaurko Gizarte Zientziak elkarrekintzan oinarritzen dira, dena guk besteekin dugun elkarrekintzaren araberakoa dela azpimarratzen dute.

Beraz, hausnarketa teoriko interesgarria da aldi berean Freirek gure proposamenerako eskaintzen diguna, eta kultura-ondarearen didaktikaren baitan egoki datorkiguna, arestian azpimarratutako hiru ideia hauek direla medio:

1. Bizitza errealarekin loturiko egoerak konpondu beharreko arazo bezala aurkeztea, horretarako hezkuntza kritikoa erabiliz, eta horretatik sortzen den gogoetak eraman gaitzala kontzientziaziora.

2. Teoria eta praktika maila berean egotea. Edukiak eraiki egin behar dira. Eta, horretarako, komunitate osoaren beharra dago.

3. Hori gauzatzeko erabiliko dugun metodologia dialogikoa izango da, baina baita taldean oinarritutako gogoeta eta ekintza ere.

\section{TEORIA SOZIOKULTURALA: VYGOTSKY ETA AUSUBEL}

Vygotsky psikologoak (1979) ere, Konstruktibismo Soziala edo Paradigma Soziokulturala izenekoaren sortzaileak, perspektiba soziokulturaletik dialogoaren garrantzia azpimarratzen digu. Horren bitartez adierazi nahi diguna da nola kokatzen den gizabanakoaren ekintza eremu kultural, historiko eta instituzionaletan. Zeregin horretan, eskolak funtzio bitartekari eta osagarria betetzen du, gogoetan oinarritutako prozesuen bitarteko elkarrekintzan eta elkarrenganako prozesuen bidez kolaborazioa eta parte-hartze aktiboa sustatuz (Oihartzabal, 2000).

Paradigma soziokultural delako horrek (paradigma konstruktibista bezala ere ulertzen da), dimentsio berri batean estaltzen du hezkuntza-prozesua, transmititzen den jakintzagaitik eraikitzen den jakintzagaira. Horrek guztiak hezkuntza-sistema osoan aldaketak egitea eskatzen digu, nola ez, baita ikaslearen nahiz irakaslearen jarreretan ere.

Beraz, eskola integratuta dagoen komunitatearen ondare soziokulturala ezagutzea eta erabiltzea beharrezkoa da ikaslearen prestakuntza in- 
tegralean, baina Valenzuela eta Viloriak (2008:262) esaten duten bezala «... para alcanzar el desarrollo pleno del mismo (ikaslearen prestakuntza erabatekoaz, integralaz, ari da), a la vez se hace necesario conocer la percepción subjetiva que poseen todos los actores del sistema educativo, desde los diversos roles que ocupan dentro de este, puesto que es determinante la posición que asumen para trasladar los saberes propios de la comunidad a la escuela y viceversa».

Paradigma hori sostengatzen duen beste teorietako bat Ausubelen Ikasketa Esanguratsua edo Adierazgarria da, eta esaldi batean laburbiltzen da: «jakin ezazu ikasleak zer dakien, eta ondoren eragin» (Ausubel, 1963:53). Ikasketa mota hori Konstruktibismoan eta Paradigma Soziokulturalean murgilduta dago, abiapuntu komun bat dutelako biek: ikaslearen aurre ezagutzak eta horiek testuinguru soziokulturalean dagoeneko integratuta. Beraz, ikasketa esanguratsuak ingurunetik jasotako informazio berriak aurretik daudenekin (gizabanakoak dituen aurre-ezagutzekin) lotu nahi direnean sortzen dira.

Izan ere, non lortzen ditu gizabanakoak bere aurre-esperientzia eta -ezagutzak? Errealitate soziokulturalean. Hortxe hartzen ditu aurre-esperientzia eta -ezagutzak, biak ala biak bere prestakuntzarako oinarri bezala erabiliko direnak. Nola? Prozesuen eta elkarrekintzen bidez, bai eremu sozialean, bai bere erakundeen bitartez (familia, eskola eta beste). Gizartean gizabanakoen eta taldeen arteko elkarrekintza horrek sorrarazten ditu ezagutza eraiki eta barneratzeko beharrezkoak diren oinarriak. Vygotskyk $G a$ rapen Hurbileko Zonaldea (GHZ) ${ }^{1}$ esaten dio horri, eta Ausubelek, berriz, Egitura Kognoszitiboetan integratzen du; baina biak gai dira ezagutzak sorrarazteko, bai era indibidualean bai elkartean, gizabanakoen arteko laguntzarekin. Alegia, ezagutzaren antolaketa ezagutzen denarekin lotuta, kultura sorrarazteko (Valenzuela eta Viloria, 2008).

Esan daiteke, beraz, Hezkuntza, Kultura eta Gizartea elkarren artean lotuta daudela, eta elkarren beharra ere badutela. Beraz, gizabanakoaren bizipen soziokulturalak beharrezkoak dira hezkuntza osatzeko, eta horrek eragina du kontzientzia sozialean, gizabanako aldi berean parte-hartzaile, aktibo, kooperatibo eta arazo eta erronken aurrean soluziobideak aurkitzeko prest daudenak sortzen baititu.

${ }^{1}$ Pertsonen garapen ebolutiboa eta ikasketak elkar eragiten dioten bi osagai direla zabaldu zuen, Garapen Hurbileko Zonaldea kontzeptu teorikoan oinarrituz. Bi garapen maila bereizten dituzte, lehenengoa Garapen Maila Erreala, "pertsona batek bere kabuz eta laguntzarik gabe egiteko gai den gauzen arabera definitzen dena» eta bigarrena, Garapen Maila Potentziala «pertsona batek gehiago dakien norbaiten laguntzaz egin ditzakeen gauzen arabera definitzen dena». Bi maila horien arteko tarteari «Garapen Hurbileko Zonaldea» esaten diote. Iturria: ALBISU, A.; SARASUA, A. Ekarpena. http://www.hikhasi.com/ artikulua/1586 . 2013ko maiatzaren 31n kontsultatua. 


\subsection{Ingurune soziokulturala: euskal ikuspegi etnokulturala. Iztueta eta Ezkurdia}

Vygotskyren paradigma eta ingurune soziokulturalaren inguruan esandakoaren ildotik jarraituz, ezin dugu baztertu Euskal Herriak bere alderdi historiko eta kulturaletik begiratuta duen izaera bereizgarria (bere nortasun soziokultural bereizgarria, hain zuzen ere) eta, hala, eskolak berea duen nortasun transmisio horretan betetzen duen zereginaren kezka.

Iztuetak (1996) eta Ezkurdiak (2004) ere argi hauteman dute Euskal Herrian beste nazio soziokultural batzuk ere badaudela, eta estatu plurinazional horretan ingurune hegemoniko bat - nazio hegemoniko bat - garatzen dela, batik bat, eta estatuan dagoen guztiaren (hizkuntza, historia, kultura) berdinketa bultzatzen saiatzen dela, ondoren curriculumaren diseinuan islatuz.

HEZIBERRI 2020 bezala ezagutzen dugun hezkuntza planteamendu instituzionala eztabaidatzen ari garen honetan (Eusko Jaurlaritza, 2015), badirudi nortasun soziokultural horren inguruko eztabaida zaharberritu egin zaigula. Izan ere, Estatuaren hezkuntza lege nagusien menpe bizi garela onartzen badugu, konturatzen gara herri bezala bizirik irauteko behar dugun arnasgunerik gabe geratzen ari garela, herritik sortutako curriculumak bazter geratu zaizkigula. Jakin dakigunean, Begoña Bilbaoren ideia erabiliz (2002), identitate kulturala etxeko eta herritarrekiko harremanetan ikasten dela.

Uste dugu, ezarri nahi dugun planteamendu didaktikotik ezin diogula errealitate soziokultural horri uko egin, eta geure egiten ditugu Iztuetak (1996) nazio etnokulturalaren oinarrizko zutabe diren herria, hizkuntza eta kultura.

\section{IKASKETA DIALOGIKOA ETA IKASKETA KOMUNITATEAK: R. FLECHA}

Ikasketarako ikusmirak zabaldu behar ditugu, besteak beste ikastetxe jakin bateko irakasleek bere haurren senideekin nahiz komunitatearekin bere curriculum proiektuak partekatu ditzaten, eta ez soilik diseinatzeko orduan, baita garatzerakoan ere (Aubert; Flecha, A; Flecha R; García; Racionero, 2009).

Eta hala da. Atzera joz gero, hezkuntzaren eta gizarte-errealitatearen arteko sinkronia ezinezkoa zela zirudienean, azken hamarkadetan familiaren eta hezkuntza zentroen arteko harremanek eta adostasunek garai batean baino garrantzi handiagoa hartzen ari dira.

Ramón Flechak (1997) pertsona helduekin 20 urtez garatutako literatur tertulietako elkarrizketa dialogikoak hartzen ditu oinarri bere teorian, eta bertan aritutako «ikasketa-komunitateak» izeneko ikuspegiaren aitzindaritzat jotzen da bera. 
Ikasketa dialogikoa hezkuntzaren komunikazio-ikusmiran oinarrituta dago. Esan nahi da, aurreko irakaskuntza- eta ikasketa-ikusmirekin alderatuta, arestian aipatu ditugun molde tradizional eta eraikitzaile gisa ezagutzen direnekin alderatuta, industria-gizarte batean eta baterako garatu zirenekin hain zuzen ere, urrats bat gehiago egiten duela. Azkenean, uste da ikasketa dialogiko delako horren ikusmira eta oinarri teorikoak koherenteak direla gaur egungo informazioaren gizartearekin, kultur aniztasunarekin eta gizartearen dialogoarekin (Flecha, 2001b).

Ikasketa dialogiko delako horren ezaugarri nagusia elkarrekintza eta komunikazioa ikasteko faktore garrantzitsutzat hartzean datza. Egindako behaketek eta ikerketek erakutsi dute errealitatearekin lotutako eremuekin hartu beharreko erabakietan, pertsonak zuzendutako dialogoen bitartez arazo-egoerak gainditzeko gai direla eta sakonago ikasten dutela, munduaren ulermen konplexuago lortzeko gai direlako. Hala ere, ikasketa mota hori ez da itxia; aitzitik, beste ikasketa tradizional, esanguratsu eta kooperatiboen ekarpenak ere jasotzen ditu. Onartzen du ez dela betirako izango, eta horregatik zabalik dago hobekuntza lortzeko, eta baita etorkizunean hori gainditzeko ere (Aubert; Flecha, A.; Flecha, R.; García; Racionero, 2009).

Ikasketa dialogikoak zazpi printzipiotan oinarritzen dira: Berdinkideen dialogoa, Adimen kulturala, Eraldaketa, Dimentsio instrumentala, Zentzua ematea, Elkarkidetza, Diferentzia edo desberdintasunen berdintasuna. Printzipio horiek ikasketa dialogikoa eta hori praktikan jartzeko gogoeta-gida bat lortu nahi dute (Flecha, 2001a).

\subsection{Ikusmira indibidualetik komunitariora}

Ohartu gara gizarte-aldaketak oso sakonak izan direla. Dagoeneko aldaketak ez direla belaunaldi batetik bestera gertatzen, lehen bezala, baita belaunaldi berean ere (Azkarraga, 2010). Gaur egungo gizarte zientziek ere ondo baino hobeto adierazten digute oraingo gizartearen botere-harremanak eztabaidagarriak direla eta gizartea bera dagozkion erabakiak hartzeko dialogo gehiago eskatzen ari zaiela gizabanakoari zein taldeari. Hori adierazteko ikusmira indibidualetik komunitariora pasatzea aholkatzen digute Beck (1998), Aubert, Flecha, A. eta R., García eta Racionero adituak (2009:30): «la revolución tecnológica de la sociedad de la información, el fenómeno social de la globalización, el aumento de los riesgos y de las opciones, entre otras características, conducen a que las personas necesitemos cada vez más comunicarnos y dialogar para tomar decisiones en torno a nuestro presente y futuro, plagados de opciones producto de nuevos valores, normas sociales e intercambios culturales».

Gertuko leihoa zabalduz gero, herritarrentzako erakunde askotan burokratizazio-prozesua nabaria izan dela hautematen da, eta horrek herritarrek harremanak galtzea ekarri duela berekin, beren parte-hartzea eta dialo- 
goa bera ere sarritan alderdikerietan bakarrik oinarritzen direla. Udalak eta ikastetxeak, adibidez, esaten ari garenaen paradigma dira, eta uste dugu burokratizatuta jarraitzen duten bitartean ez dagoela dialogorako biderik.

Baina egoerak aldatu egiten dira. Hezkuntzaren eremuan, eta azken dinamikei jaramon eginez gero, badirudi familiek eta komunitateek euren seme-alaben zentroaren eta hezkuntzaren diseinuan eta garapenean parte hartu nahi dutela, eta badirudi poliki-poliki kontsentsuan eta dialogoan oinarritutako ekintza komunitarioak zabaltzen doazela. Halaber, esan daiteke udalek eta herritarrek azken urteotan hainbat parte-hartze prozesu jarri dituztela martxan eta prozesu berriak zabaldu dituztela elkarrekintzak sustatzeko (Gipuzkoako Foru Aldundia, 2007). Beraz, esperientzia horiek onerako aldaketa demostratu dute; alegia, garai bateko komunitate eta ikastetxeen (eta gehitu beharko genuke erakundeen) arteko botere tradizionaletik dialogikora pasatzen ari garela, eta horrek ikasleen ikasketak hobetzen laguntzeaz gain, familien parte-hartzeak haurren elkarrekintzaren koordinazioa askoz errazagoa izatea ekarri du.

Horretan dago aldaketa. Izan ere, «ikasketa esanguratsuan» oinarritutako (Ausubel, 1962) industria-gizarteko irakaskuntza eta ikaskuntzaren ikusmira konstruktibista batekin lotuta bazegoen ere, , gaur egun, informazioaren gizartean, aldaketa bat sumatzen dugu irakaskuntzan eta ikaskuntzan, zeinaren arabera hezkuntza-ikaskuntza gero eta gehiago dialogoan, elkarrekintzan eta komunikazioan oinarritzen den. Ikasketaren komunikazio-ikusmira horretatik dator, hain zuzen, Ramón Flecharen (1997) ikasketa dialogikoa, informazioaren gizarteak erreferentziazko testuinguru historiko eta sozial bezala aintzat hartzen duena, eta poliki-poliki ezartzen ari dena, dagoeneko ezagutzen dugun beste ikaskuntza-molde askoz indibidualistago eta ez elkarrekintzarik, ez eta testuinguru soziokulturalekin loturarik gabeekin partekatzen dena.

Aubert, Flecha, A. eta R., García eta Racionero adituen (2009) ideia erabiliz, subjektuari ematen diote garrantzia, bere funtzio aktiboa ikasketan eta, aldi berean, subjektua bera gainditzen duen ikasketaren subjektuen artekoaren mesederako. Alegia, giza harremanak eta horien eta erakundeen arteko dialogoa gero eta garrantzitsuagoa da. Vygotskyk (1996) esaten zuen bezala, orain gure barruan dugun guztia beste pertsona batzuekin partekatua izan da.

Eta azken ideia hori da R. Flechak (2001b) «ikasketa-komunitateak» deituriko horretan sakontzen duena, garapen kognitiboak ingurune soziokulturalarekin duen loturaz aberastu behar duela esatean, baina ingurunea eraldatzeko xedearekin, ez soilik inguruneari egokitzeko planteamenduarekin. Itxura denez ezin ikas daiteke ezer lagunekin batera ez bada. Alegia, transposizio bat gertatu dela hauteman daiteke: garai batean ikastea bakarkako jarduera zela pentsatzetik, lagunekin hobeto ikasten dela pentsatzera igaro gara. Esan nahi da ezagutza ez dela jarduera indibidualaren emaitza, gizarte-harremanen ondorioa baizik. 
Elkarrekintza horren garrantzia ukatu gabe, eta gizarte-harremanak tarteko, Arrietak (2000) adierazten digu haurraren garapena nola doan behatu eta ikertu nahi bada, ezinbestekoa dela haurrak egiten duenari soilsoilik ez behatzea, haurrarekin dagoen helduak egiten duena ere aztertu behar dela.

Hezkuntza-ikasketan komunitate barruan gertaturiko elkarrekintza guztiek eragina dute, eta haurren ikasketa-prozesuan irakaslea bera baino pertsona gehiagok parte hartzen dute. Bestalde, ikasketa-prozesua hainbat testuingurutako (eskola, etxea eta komunitateko beste espazioetako) jendeak haurren ikasketa-prozesuan duen parte-hartzearen araberakoa ere bada. Beraz, oro har, gelan gertatzen denarekin gero eta lotura gutxiago dauka ikasketak, eta gero eta gehiago eskolan eta eskolatik kanpo gertatzen den koordinazioan (Elboj, Puigdellívol, Soler, Valls, 2002). Informazioaren gizartean ikasketa lotuago dago haurrek bere ingurukoekin dituzten harremanekin; irakasleez gain senitartea, lagunak, aisialdi-monitoreak... daude, eta baita gelaz kanpoko espazioetan ere (liburutegia edo informatikako gela, etxea, auzo elkartea...). Beraz, ikasketa dialogikoa hainbat espaziotatik abiatzen da.

Eta espazio horren baitan dauden pertsonen arteko (berdin diolarik horien maila akademikoa, estatus soziala, maila ekonomikoa, jatorri kulturala, etnia, iritzia) elkarrekintzaren bitartez sortzen da jakintza, esperientzia, bizipen eta sentimenduak. Prozesu horren bitartez gertatzen den ikasketa gai da, alde batetik, dialogoa hasi aurretik pertsonak zekiena eraldatzeko, ezagutza zabaldu eta konplexuagoa bihurtzen duelako, eta, bestetik, haren inguru soziokulturala nahiz norbanakoa eraldatzeko (Aubert, Flecha, A. eta R., García eta Racionero 2009).

Ikasketa dialogikoan irakasleak, familia eta adineko beste pertsona batzuk dialogoa bideratzen duten pertsonak dira, kulturak berak sorrarazten duen muga gaindituz eta gureak ez direnekin bat eginez (Giroux, 1997). Perspektiba komunikatibotik irakasleok inguruarekin elkarrekintzak garatzen eta hori esanguratsua izateko prozesuak sortzen jakin behar dugu, berdintasuna eta komunitate sena azpimarratuz, non komunikazioa ez den soilik irakasle eta ikasleen artekoa, baizik eta ingurune sozial eta kultura horren barnean dauden guztien artekoa. Hala, ikusmira konstruktibistak markatzen duen komunikazio kontzepzioa zabalduz doa hezkuntzaikasketan komunitate osoko pertsona adinduen parte hartzea bultzatuz, eta hala haurrak eurekin harremanetan jarriz ikasten dute. Haurrek irakasleekin baino pertsona gehiagorekin ikasten badute, orduan irakaskuntza-ikaskuntza prozesuak gelan edo eskoletako espazioetan baino toki zabalagoan gertatzen dira. Haurrek kalean, elkarteetan, aisialdietan, ludotekan, liburutegian eta abarretan ikasten dute. Eta pertsona ugarirekin: aitona-amonekin, osaba-izebekin, anai-arrebekin, monitoreekin... eta beren eguneroko harremanetako eragileekin. Beraz, konstruktibismoaren arabera irakaskuntza- eta ikaskuntza-prozesuen azterketarako baliatzen den elkarrekintzan 
oinarritutako triangelua (irakaslea, ikaslea eta edukia), informazioaren gizartean labur geratu da eskolako ikasketa aztertzeko eta ulertzeko; izan ere gaur egun ingurune sozioekonomiko eta soziokulturalen eraginez elkarrekintza areagotu den honetan hezkuntza eta espazio eragileak ugaritu egin dira, haurrek elkarrekintza biderkatuz eta zabalduz.

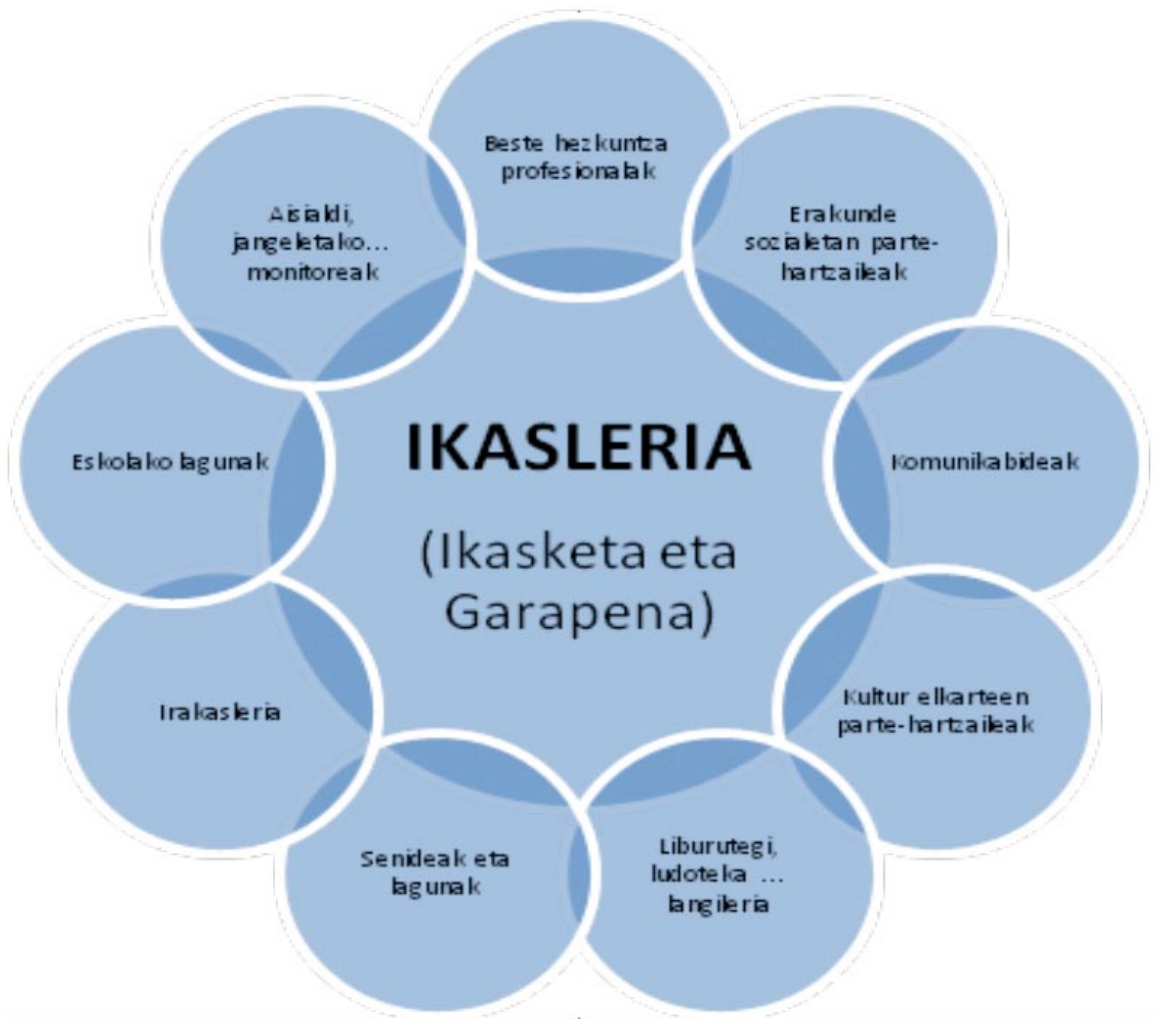

Iturria: AUBERT, A.; FLECHA, A.; GARCÍA, C.; FLECHA, R.; RACIONERO, S. (2009): Aprendizaje dialógico en la Sociedad de la Información. Barcelona: Hipatia, 87. or. Egileak egokituta.

\section{Lehen irudia \\ Elkarrekintzarako Unitateak}

Aubert, Flecha, A. eta R., García eta Racionero-k (2009: 88) dioskuten bezala:

«En este sentido, una de las actuaciones que alrededor del mundo se está observando que tiene más éxito es la inclusión en los centros escolares de agentes educativos de contextos no escolares». 
Horrek berez eskatzen du komunitatearen hezkuntzako eta hezkuntzaz kanpokoen arteko harreman-koordinazioa gehiago sustatzea, eta, aldi berean, eraldaketa bat, komunitate horretan parte hartzen duten eragile guztien eskola-ikasketaren barneko zeregina aitortuz. Norena? Hezkuntza formaleko zentroena, ez formalarena, etxearena, kultur erakundeena, gizarte-erakundeena, aisialdi edo denbora libreko zentroena...

\section{GARDNER ETA IKASKETA TESTUINGURU EZ FORMALETAN}

Dagoeneko asko jardun da Gardnerek (1983) hain ospetsua bihurtu duen adimen anitzaz. Gure helburua berak hezkuntza ez formaltzat hartzen duena gure nahietarako geureganatzea da.

Howard Gardner (2005) psikologiako zientzialari ospetsuak zazpi adimen mota identifikatu zituen hasiera batean: hizkuntza-adimena; adimen logiko-matematikoa; adimen espaziala; norberaren gorputzaren gaineko adimena (edo adimen kinesikoa); musika-adimena; pertsonen arteko harremanetarako adimena; norberaren burua ezagutzeko eta kudeatzeko adimena. Badirudi, baina, esandakoetatik aparte, beste batzuk ere identifikatzen joan dela denbora pasa ahala (naturala, morala, umorea, intuizioa, sortzailea, janaria prestatzea, usaimen-sena, edo existentziala ere, alegia, bizitza, heriotza eta azken errealitateari buruzko galderak planteatzeko eta neurtzeko adimenarena).

Esan beharrik ez dago gizaki guztiok ez ditugula adimen horiek neurri berean garatuta. Gizaki bakoitzak du maila jakin bat, biologikoki, ingurunearekin nahiz kulturarekin izandako elkarrekintzan garatutakoa, pertsonok ez ditugu modu berean erabiltzen, eta eskolan hauteman daitezkeenak era mugatu batean; izan ere ikasle gehienak batean edo bitan nabarmentzen dira (Guzman, B.; Castro, S., 2005).

Baina eguneroko zereginarekin bat eginez, nola aplikatu adimen anitz hori gelan? Zer ikasketa mota eskaini adimen-gaitasun desberdinak garatzeko? Irakasteko zer aktibitate, material eskaini? Zer estrategia didaktiko jarri martxan? Nola erabili kultura-ondarearen mesederako?

Gizarte Zientzietako irakasleak, oro har, ikasketa prozesua gela barruko edukien eta prozeduren osagarritzat hartzen du ikasketa ez formala. Benejamek (2003) adierazten digu zer muga duten teoria konstruktibistaren baitan (Piageten ikusmoldean) egindako esperientzia, proposamen eta ikerketa proiektuek. Izan ere, Piageten interpretazioaren arabera pentsatzen da eskolak haurrari ikasteko aukerak eskaini behar dizkiola, ikasleak berak indukzioz ikasi dezan; alegia, ezagutzak aurkitu eta eraiki.

Eskolako irteerak oinarrizkoak dira Gizarte Zientzia nahiz Natur Zientzia arloetan, pentsatzen delako behaketa zuzenaren bitartez aurkitutakoa gelan interpretatu egingo dela ondoren. Benejamek, baina, adierazten digu errealitate horrekiko egiten dugun bitartekari gabeko behaketa hori motiba- 
garria izan arren, gaur egun zalantzan jartzen dela horren baliagarritasuna. Izan ere, Calafen arabera (2008):

1. Ezagutza produktu pertsonala da, baina baita soziala ere. Alegia, dudarik ez dago ikasteko prozesuan ikaslearen aktibitate mentala beharrezkoa dela, baina hori bezain garrantzitsua da irakasle edo beste bitartekariren bat egotea.

2. Behaketak eta esperimentazio zuzenak ez du ezagutza zuzena bermatzen. Behaketa zuzena behatzailearen aurreiritziekin «kutsatuta» dator, bere pertzepzioarekin: beraz, esperimentazioan oinarritutako metodo induktiboak ez du ezagutza zuzena bermatzen.

3. Behaketak azaleko ezagutza ematen du. Aurkikuntzan oinarritutako metodoa ikasleak errealitatea bitartekaririk gabe behatu dezan lortzera bideratuta dago. Mendebaldeko kulturako tradizio pedagogiko aurrerakoiek behaketa zuzenean jarri dute hezkuntza eta ikaskuntza on batera bideratzeko premisa onena.

Hala ere argitu beharko litzateke Benejam (2003) beraren aburuz zalantzazkoa da soilik behaketa zuzena lantzena; alegia, behaketa baliagarria izango da identifikatzeko, alderatzeko, sailkatzeko, orokortzeko eta interesa pizteko, zergatiak eta fenomenoak ulertzeko, baina ez da nahikoa. Hots, bitartekari baten beharra dago, horren bitartez 1) ikasleak zergatien arrazoi sakonagoak uler ditzan, 2) ikasleak behatzen ari den horren barneko esanahia uler dezan.

Museo, interpretazio-zentro edo ondasun kultural batera joaten garenean behaketa baliabide didaktiko ona da interesa sortzeko, bai noski, baina ikasleak soilik egoera horretan geratuko balitz, ez genuke ikasketa esanguratsua lortuko. Aldiz, ikaslearen interesak ezagutu asmoz irakasle eta bitartekarien arteko elkarlana egongo balitz eta, ostean, bitartekari horren ekarpena egindako eskaerari egokitzeko, orduan bai lortuko litzateke ezagutza hori esanguratsua izatea.

Eskolen krisiaz eta gainbeheraz hitz egiten digunean, Gardnerek ere (2005:110) eskoletan sarriegi testuingururik gabeko edukiak lantzen direla dio, errealitatean gertatzen denarekin loturarik gabeak. Hezkuntza formala, beraz, gaizki dago, eta agian formalak ez diren beste erakunde batzuen beharra ere bada:

«... las escuelas se han convertido poco a poco anacrónicas, mientras que los museos han conservado la capacidad de entusiasmar a los estudiantes, de enseñarles, de estimular su capacidad de compresión y, lo más importante, de ayudarles a asumir las responsabilidad de su propio aprendizaje futuro». 


\subsection{Gardner, hezkuntza komunitatearen aldeko}

Baina guretzat Gardnerek duen interesa haratago ere badoa, gure ekarpen horren oinarri teorikorako beste zutabe bat ere badelako; izan ere, berak ere ezinbestekotzat jotzen du gizarte-eragileen beharra, bai eskolaren egunerokorako, bai ikasleen ikasketa eta irakaskuntza prozesuaren barruan ere. Gero eta jakintza zabalagoak eta eskola ordu gutxiago dugun honetan, orduan eta beharrezkoagoa da komunitateko eragileen parte-hartzea. Eta, besteak beste, gurasoak eskolan parte hartzera animatzen ditu; eta komunitatearekin ere gauza bera egiten du, nagusiki bi funtzio finkatuz: bata, haurrek beren lanak erakuts ditzaten museo bat sortzea proposatzen du, baina baita pertsona ezagunen lanak ezagutzeko ere, artistekin harremana izateko. Bestea, eta hau izan daiteke agian berrikuntza aldetik harrigarriena, berak definitzen dituen adimen anitz bakoitzeko talde bat osatzea, haurrek jakin dezaten edozein zalantza, galdera, aholku eta abarren aurrean nora jo, beraien eredu izan daitezen eta lan mundura sartzen lagun diezaien:

«Participación de la comunidad. En el pasado, la gente se contentaba con descargar el peso educativo en la escuela. Esta opción ya no es viable. Las crecientes demandas cognitivas de la escuela, los graves problemas de nuestra sociedad actual y la necesidad de apoyo que tienen los estudiantes, que va más allá del periodo diario de nueve a tres, hacen necesario que otros individuos e instituciones contribuyan al proceso educativo. Además del apoyo por parte de miembros de la familia y de otros adultos, entidades como las empresas profesionales y especialmente los museos tienen que implicarse de forma mucho más intima en el proceso educativo» (Gardner, 2005: 114-115).

Alabaina, eskola-familia-komunitatea hirukoteak elkarrekin lan egiteko asmoak, antolaketa eta kudeaketa arazoak sor ditzake, baina -Gardneren hitzetan - eskolan beste irudi akademiko berri bat sortuaz konpondu daitezkeenak ; alegia, hiru kideen arteko lotura eta komunikazioa bermatuko lukeen irakasle bat. Ildo horretatik ere, eta gero ikusiko dugun bezala, eskolaren eta komunitatearen artean elkarlana beharrezkoa dela adierazten digu (Gardner, 2005:107-108):

«El objetivo del gestor escuela-comunidad consiste en incrementar la posibilidad de que los estudiantes descubran una vocación o una afición que encaje con su propio perfil de inteligencia».

Sanz de Acedok dioskun bezala (2000), arestian irakurritako proposamenak sekulako garrantzia izan beharko luke, bai ikasketa-planak egiterakoan, baita hezkuntza-sistema osoaren politika definitzerakoan. Hala, zera aurreikusten du: Lehen Hezkuntza ikaslearengan adimen anitz garatzean oinarritzen da; Bigarren Hezkuntzan, berriz, ikasle bakoitzak aukeratutako 
bokaziozko esperientzian, garbi dago produktuak goi-mailan egon diren ikasketetan eragina izango duela. Unibertsitatea izan edo lanbide-heziketakoa izan, irakasleek jakingo dute zer profilekin (eduki, jarrera eta motibazio) datorren ikaslea. Baldintza egokiak uztartzeko ikasleak dituen interesekin eta gizarteak eskatzen duenarekin.

Beraz, hezkuntza formala, ez formala elkartzeko estrategikoa ikusten dugu Gardneren proposamena kultura-ondarearen eta hezkuntza-komunitatearen uztarketan marko teoriko honen bueltan delakoa diseinatzeko.

\subsection{Adimen anitza, curriculum edukiak eta metodologia kultura ondarearen ezagutzaren mesederako}

Irakasleak hainbesteko adimen aintzat hartu behar horretan, Gardneren arabera (2005), edukien aukeraketa egin behar da, sailkapen bat, lehentasunak aukeratuz. Berak proposamen bat eskaintzen digu, eta Lehen Hezkuntzarako hiru eduki akademiko soilik ikastea (matematika, hizkuntza eta gizarte edo natur zientziak) aholkatzen du, aktibitate fisikoren bat eta arteadierazpena. Edukiak aurkezterakoan, irakasleek eta ikasleek edukien eta adimenen arteko harremanak ezarri behar dituzte.

Are gehiago, «etorkizuneko eskolaz» diharduenean ongi adierazten du ez dela eskola uniformeen aldeko, eta gizabanakoari atxikitako curriculuma bultzatu beharra aurreikusten du. Eta nola diseinatu, bada, gizabanakoari zuzendutako eskola bat? Eskola-eremuak edo eskola-sistema berak onartu eta diseinatu beharko lituzkeen hezkuntza-funtzio hirukoitza eratuz: ebaluatzaile-espezialista (1), ikasleen curriculumaren kudeatzailea (2) eta, guri interesatzen zaiguna, eskola-komunitatearen kudeatzailea (3).

Lehena ume bakoitzaren eguneroko egoeraz arduratuko litzateke. Bigarrenak, berriz, ikaslearekin batera ikasleari bere curriculum-materiak ondo aukeratzen aholkatuko dio. Eta, hirugarrena komunitatearen barruan ikaslearentzat onak izan daitezkeen hezkuntza-aukerak aurkitzen saiatuko da. Irudikatu nahi duen eskola, bada, oinarrizko diziplinetan ikasleen ezagutza sakona estimulatzeko konprometitu beharko litzateke.

Ordutegia eta metodologia-proposamena ere egiten digute: goizetan ohiko materiak jorratu bai, baina ez ohiko metodologiak erabiliz: matematika, zientzia, gizarte zientziak, idazmena eta idazketa, baina dena, proiektuen bidez (zirriborroak gordeaz, errebisioak eginez, azken produktuak diseinatuz). Ikaslearen lana aztertuz informazioa kudeatu eta adierazteko pentsamendua eta etorkizunera begira dituen proiektuen bidez ebaluatzen da azken produktua.

Arratsaldetan, berriz, goizekoaren luzapena izango da. Horretan irakaslea eta ikaslea komunitatean iraultzen dira, ikasteko esperientzia berrien bila (ez nahastu eskolaz kanpoko irteerekin). Txikienak, adibidez, parkera, museora, antzezpen batera joatea: 
«Ya sea en el museo o en el rico entorno de nuestra escuela, se permite a los niños a explorar con libertad y se les anima a que hagan preguntas. Los maestros, los auxiliares y otros adultos (incluyendo el personal del lugar que se visita) toman nota mental o escrita acerca de lo que los niños observan. ¿Qué estudiantes muestran interés o habilidad hacia alguna actividad o exposición concreta? ¿Qué preguntas hacen? ¿Qué tareas les resultan más dificiles» (Gardner, 2005:111).

\section{ONDORIOAK}

XX. mendearen bukaeratik aurrera, kultura-ondarearen erabilera gero eta arrakastatsuagoa izateaz gain, gero eta gehiago sozializatu da kulturareren demokratizazioaren bidez. Kultura-ondarearen ereduez eta objektuez gain, hartzailea bera bihurtu da helburu, eredu edo objektu horren nondik norakoa hobeto interpretatzeko subjektu nagusi.

Ezagutu, ulertu, baloratu eta jardun pedagogia-dimentsioak dira ondare-hezkuntzara aplikatzen diren gaurko erreferenteak (Fontal, 2003), bai edukien sistematizaziorako bai hezkuntza estrategietarako. Horiek, Delorsek (1999) egindako gaitasunen proposamenetan oinarrituta daude: ezagutzen, egiten, izaten eta elkarbizitzen ikasi.

Dimentsio horiek ikasketa dialogikoan ere oinarritzen dira, zeinak elkarrekintza eta komunikazioa dituen ezaugarri nagusitzat: pertsonekiko harremanetan, gelaz kanpoko espazioetan, holako eta halako eragileekiko elkarreraginean eta euren jakintza, esperientzia, bizipen eta sentimenduak jaso eta adierazterakoan. Komunikazioa, beraz, ez da soilik irakasle-ikasleen artean gertatzen, ingurune soziokultural horretan dauden elementu guztien artean ere bai. Horrek hezkuntza eragileen (eta ez direnen) arteko harreman-koordinatuak eta jarrerak aldatzea eskatzen du.

Izan ere, Deweyk (1985) hezkuntza ez formalari (edo hezkuntza asistematikoari) ematen dion garrantziari erreparatu nahi diogu, eta hezkuntza bera esperientzia metaketa bat dela ohartarazi, bai eta horretarako ezinbestean elkartruke komunitarioa baten beharraz azpimarratu ere.

Freire ere bat dator Deweyk adierazitakoarekin, sintonian dago; izan ere, jakintza eraikuntza honetan, eta Freirek (1985) adierazten digun hezkuntza bankarioa dena saihestu nahian, hezkuntza komunitatearen beharra errebindikatzen du, elkarrekintza eta dialogoan oinarrituta. Praktikan, Ramón Flechak (1997) ikaskuntza komunitarioa izeneko proiektu nahiz esperientzietan gauzatuko duena.

Jakintza eraikuntza horri paradigma soziokulturala gehituz (Ausubel, 1963; Vygotsky, 1979), eta Euskal Herria nazio soziokulturaltzat hartuz gero, nola adierazi beharko litzaiokteke bera?, horra beste gakoa. Iztueta (1996) eta Ezkurdiak (2004) adierazitako ildotik, aurrezagutzak eta esperientziak ahalik eta esanguratsuen eta eraikitzaileenak izan daitezen, errea- 
litate soziokultural gardena (ez nahasia, gaur bezala) sustatu beharko litzateke.

Eskolaren krisia aitzakia, Gardnerrek (2005) berak ere , beste erakunde ez formal batzuekin harremanetan jarri, elkarrekintzan aritu, eta komunitatearen parte-hartzeari ateak irekitzea aldarrikatu du, eta horretarako komunitatea iraultzea.

Beraz, eskolaren egunerokorako, ikasleen ikasketa prozesurako eta irakasleen irakaskuntzarako ezinbestekoak dira gizarte-eragileak; eskolak, familiak eta komunitateak elkarrekin lan egiteko asmoak eta proposamenak garatu behar dira.

Gaurko ikastetxe askok darabilte komunitatearen metafora garai bateko hezkuntza antolatzeko eredutik aldentzeko. Komunitate barruan denek dute hitza, baina bideragarria izan dadin eta aurreikusitako helburuak bete ditzan, bertako kide guztiek elkarrekintzan aritu behar dira, tolerantzia eta dialogo barruan.

Uste dugu hala eginez arestian aipatutako paradigma komunitarioa, elkarrekintzan eta dialogoan oinarritua, aproposa izan daitekeela kultura-ondarearen transmisioarekin bat eginda, hezkuntza egitasmoa aurrera eramateko.

\begin{abstract}
What is the role of education, from the perspective of participation, in the management of cultural heritage? In our view, its challenge is to articulate, in the best way possible, the space between educational managers and social agents, without losing sight of its own objectives and strategies, and considering every form and stage in the formal education system. In fact, it is advisable to involve children and adolescents in the protection and dissemination of cultural heritage. On the other hand, in the case of the non-formal education the challenge lies in the creation of educational processes between social agents and educational managers. What strategy should be implemented in order to shape all this? In the present article we attempt to answer this question, building on the views of several experts.
\end{abstract}

Keywords: Cultural heritage. School community. Transmission. Dialogue. Sociocultural context. Primary and Secondary Education. 
Desde el ámbito de la participación ¿cuál es la función de la educación en la gestión del patrimonio cultural? El reto sería el articular lo mejor posible la distancia entre los gestores de la educación y los agentes sociales, cada uno con sus objetivos y estrategias. Dentro de la educación formal, y en cualquier modalidad y etapa del sistema educativo, estaría bien implicar tanto a los niños como a los jóvenes en su conservación y difusión. En la educación no formal, el reto es crear procesos de enseñanza entre los agentes y los gestores sociales. Pero para lograrlo ¿qué estrategia deberíamos seguir? El objetivo principal de este artículo es responder a esta cuestión usando los distintos puntos de vista de varios expertos.

Palabras clave: Patrimonio cultural. Comunidad escolar. Transmisión. Diálogo. Contexto sociocultural. Educación Primaria y Secundaria.

Quelle fonction remplit l'éducation, du point de vue de la participation, dans la gestion du patrimoine culturel? Son défi consiste, selon nous, à articuler le mieux possible l'espace entre les responsables de la gestion de l'éducation et les agents sociaux, sans pour autant perdre de vue les objectifs et les stratégies qui lui sont propres, c'est-à-dire en considérant n'importe quelle modalité ou étape liée au système d'éducation institutionnel. Car il convient de faire participer les enfants et les adolescents à la protection et à la diffusion du patrimoine culturel. En revanche, le défi de l'éducation non institutionnelle réside dans la création concertée de processus d'enseignement par les agents et les gestionnaires. Et pour donner forme à tout cela, quelle stratégie doit-on mettre en ouvre? Nous tentons dans le présent article de répondre à cette question en nous fondant sur les propos de nombreux experts.

Mots clé: Patrimoine culturel. Transmission. Communauté scolaire. Dialogue. Contexte socioculturel. Enseignement Primaire et Secondaire.

\section{ERREFERENTZIAK}

Armstrong, T. (1999). Las inteligencias múltiples en el aula. Buenos Aires: Manantial.

Arrieta, E. (2000). Ikaskideen arteko eta irakasle-ikasleen arteko harremanak eskolan. Hik hasi, 5. monografia, 40-51.

Aubert, A.; Flecha, A.; García, C.; Flecha, R.; Racionero, S.; (2009). Aprendizaje dialógico en la Sociedad de la Información. Barcelona: Hipatia. 
Ausubel, D. P. (1962). A subsumption theory of meaningful verbal learning and retention. Journal of General Psychology, 66, 213-224.

Ausubel, D. (1963). The psychology of meaningful verbal learning. New York: Grune and Srtaton.

Azkarraga, J. (2010). Hezkuntza, gizartea eta eraldaketa kooperatiboa. Zenbait gogoeta, Gizabidea Fundazioaren hausnarketa estrategikorako. LANKI: Mondragon Unibertsitatea.

Beck, U. (1998). La sociedad del riesgo: hacia una nueva modernidad. Barcelona: Paidós.

Benejam, P. (2003). Los objetivos de las salidas. Iber, 36, 7-12.

Calaf, R. (2009). Didáctica del patrimonio. Epistemología, metodología y estudio de casos. TREA: Oviedo.

Delors, J. (1999). XXI. menderako hezkuntzari buruzko hezkuntza: Altxor ezkutua. Nazioarteko batzordeak UNESCOri egindako txostena. Vitoria-Gasteiz: Eusko Jaurlaritza.

Dewey, J. (1982). Democracia y Educación. Buenos Aires: Losada.

Dewey, J. (1985). Democràcia i escola. Vic: Eumo editorial/Diputació de Barcelona.

Dewey, J. (2004). Experiencia y educación. Madrid: Biblioteca Nueva.

Elboj, C.; Puigdellívol, I.; Soler, M.; Valls, R. (2002): Comunidades de aprendizaje. Transformar la educación. Barcelona: Graó.

Ugartetxea, A. (1997). Elkarrizketa. Hik hasi, 20. http://www.hikhasi.eus/ artikulua/283. 2011 ko maiatzaren 11ean kontsultatua.

Ezkurdia, G. (2004). Curriculuma eta ingurunea Euskal Herrian. Donostia: Utriusque Vasconiae.

Flecha, R. (1997). Compartiendo palabras. Barcelona: Paidós.

Flecha, R. (2001a). Compartiendo palabras. El aprendizaje de las personas adultas a través del diálogo. Papeles de Pedagogía. Barcelona: Paidós.

Flecha, R. (2001b). Ekarpena. Hik hasi, 56. http://www.hikhasi.eus/artikulua/640. 2011 ko maiatzaren 11ean kontsultatua.

Fontal, O. (2003). La educación patrimonial. Teoría y práctica en el aula, el museo e internet. Trea: Gijón.

Freire, P. (1975). La educación como práctica de la libertad. México: Siglo XXI editores.

Freire, P. (1985). Pedagogía del oprimido. Buenos Aires: Siglo XXI.

Gardner, H. (1983). Frames of mind: The theory of multiple intelligences. Nueva York: Basic Books.

Gardner, H. (2005). Inteligencias múltiples. La teoría en la práctica. Barcelona: Paidós.

Gipuzkoako Diputazioa (2007). Gipuzkoa parte-hartzen programa. http://www. gipuzkoapartehartzen.net/index.php?lang=eu. 2014ko azaroaren 11 eta $12 \mathrm{an}$ kontsultatua.

Giroux, H. (1997). Cruzando límites. Trabajadores culturales y políticas educativas. Barcelona: Paidós.

Guzmán, Belkys eta Castro, S. (2005). Las inteligencias múltiples en el aula de clases. Revista de Investigación, 58, 177-210.

Iztueta, P. (1996). Intelligentsia kimaturen orbelak. Irun: Kutxa Fundazioa.

Nicholson-Nelson, K. (1998). Developing students Multiple Intelligences. Jefferson: Scholástic Proffesional Books. 
Oihartzabal, I. (2000). Vigotskiren elkarpena hezkuntzaren mundura. Hik hasi, 5. monografia, 12-23.

Puigdellívol, I. (2001). La educación especial en la escuela integrada. Una perspectiva desde la diversidad. Barcelona: Graó.

Sanz de Acedo, M.L. (2000). Gardner, H. Adimen anitzen teoria: Hezkuntza jomuga (I). Hik hasi, 51, http://www.hikhasi.eus/artikulua/598. 2011ko maiatzaren 30ean kontsultatua.

Tejados, L. (2001). Teoriak. Paulo Freire (1921-1997). Hik hasi, 56. http://www. hikhasi.eus/artikulua/642. 2011ko maiatzaren 11ean kontsultatua.

Tejados, L. (2005). Paulo Freire, 1921-1997. Pedagogo sortzaileak teorien iturburu. Hik hasi, 17. monografia, 80-84.

Valenzuela, T.; Viloria, N. (2008). Estrategias metodológicas para la enseñanza del patrimonio cultural local en el área de educación para el trabajo. Caso: Unidad educativa 'Juan Bautista dalla Costa' del municipio Boconó del Estado de Trujill. Investigación y Posgrado, 23, 251-280.

Vygotsky, L.S. (1979). El desarrollo de los procesos psicológicos superiores. Barcelona: Crítica.

Weber, M. (1977). Economía y sociedad. México: Fondo de Cultura Económica. 